\title{
Peripheral Blood Examination Findings in SARS-CoV-2 Infection in Pediatric Patients
}

\author{
ROMEL SEGURA ${ }^{1}$, Stefanie Sanchez ${ }^{1}$, Juan Rojas $^{2}$, and Gaston Castillo ${ }^{1}$ \\ ${ }^{1}$ Fundacion Clinica Infantil Club Noel \\ ${ }^{2}$ Universidad Libre
}

June 5, 2021

\begin{abstract}
Background The findings of peripheral blood examination (PBE) in SARS-CoV2 infection in pediatrics patients have not been fully described, the reports have been done on the adult population so far. In this study we showed the characteristics in the PBE in SARS-CoV2 infection in the pediatric population. Methods Descriptive, observational, longitudinal, prospective study. Information from the medical records of pediatric patients $<17$ years of age with a diagnosis of SARS-COV-2 (positive PCR test) was analyzed and peripheral blood smear examination was performed. Results 16 pediatric patients with a diagnosis of SARSCoV-2 /COVID-19 were evaluated. 100\% of the patients had PBE done, 62.50\% (10/16) had no morphological alteration of the erythroid cell line, the erythroid changes were: anisocytosis and echinocytosis in $12.5 \%(2 / 16)$, in white cell line a predominance of plasmacyte lymphocytes was found in 37.5\% (6/16), followed by hyposegmented neutrophils "Pelger-Huet anomaly" $31.25 \%$ (5/16), hypersegmented neutrophils $12.5 \%$ (2/16), atypical lymphocytes $18.75 \%$ (3/16), granular lymphocytes in $6.25 \%(1 / 16)$, prolymphocytes in $6.25 \%$ (1/16), hyposegmented eosinophils in $12.5 \%(2 / 16)$. Conclusion Plasmacytoid lymphocytes and large granular lymphocyte are seen more frequently in pediatric patients with COVID-19. Abnormalities in the neutrophils with acquired Pelger-Huët anomaly (APHA) were important findings in pediatric patients with COVID-19.
\end{abstract}

\section{Hosted file}

PAPER Pediatric Blood and Cancer 17 Mayo de 2021.docx available at https://authorea. com/users/418114/articles/524981-peripheral-blood-examination-findings-in-sars-cov-2infection-in-pediatric-patients

\section{Hosted file}

Table 1 mayo 17 2021.docx available at https://authorea.com/users/418114/articles/524981peripheral-blood-examination-findings-in-sars-cov-2-infection-in-pediatric-patients

\section{Hosted file}

table 2 Mayo 17 2021.docx available at https://authorea.com/users/418114/articles/524981peripheral-blood-examination-findings-in-sars-cov-2-infection-in-pediatric-patients 
Figure $1 \mathrm{~A}$

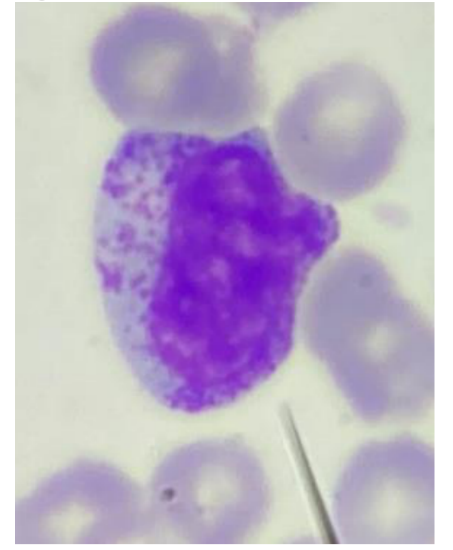

Figure $1 \mathrm{C}$

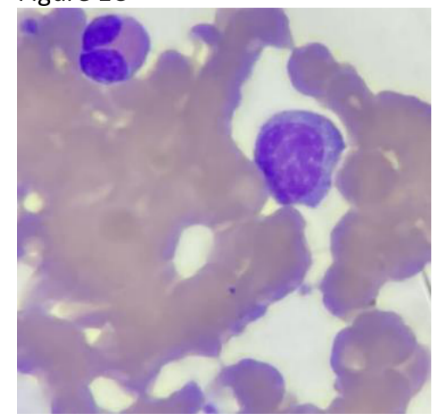

Figure 1B

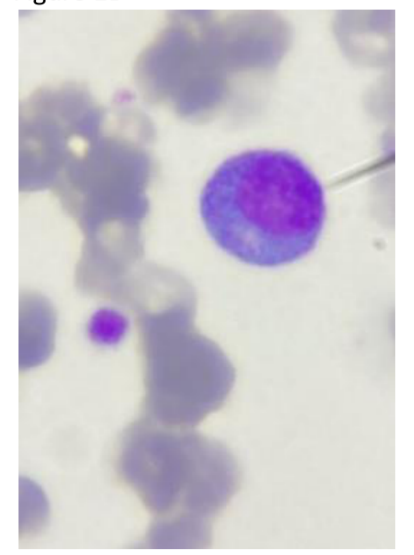

Figure 1D

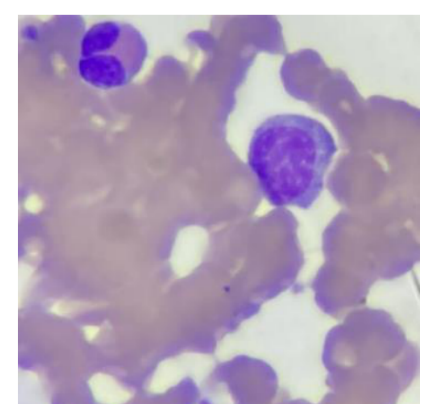

Image 1. Morphologic findings in peripheral blood smears in patients with coronavirus disease (Wright stain, $\times 100$ ). A-B, Large granular lymphocyte. C, Downey type III lymphocyte. D, Pelger- Huet anomaly. 